\title{
Effect of Commercial Cellulase Enzymes on Ethanol Production from Pretreated Rice Straw at High Solid Loading
}

Teerapatr Srinorakutara ${ }^{1}$, Yuttasak Subkaree ${ }^{1}$, Nassapat Boonvitthya ${ }^{2}$, Thapparait Kunhanon ${ }^{1}$ and Nantana Bamrungchue $^{1}$

1. Department of Energy Technology, Thailand Institute of Scientific and Technological Research (TISTR), Pathum Thani 12120, Thailand

2. PTT Research and Technology Institute, PTT Public Company Limited, Ayutthaya 13170, Thailand

\begin{abstract}
Effect of commercial cellulose enzymes was investigated by batch enzymatic hydrolysis at $15.0 \%$ (w/v) solid. It was found that the best commercial cellulose enzyme was Cellic ${ }^{\circledR}$ CTec comparing to Accellerase $1000^{\mathrm{TM}}$ and Accelerase $1500^{\mathrm{TM}}$. The Cellic ${ }^{\circledR}$ CTec gave the highest reducing sugar concentration and rice straw conversion. Moreover, when the hydrolysate obtained from hydrolysis using Cellic ${ }^{\circledR}$ CTec was fermented by Saccharomyces cerevisiae TISTR 5596, it would give the highest ethanol. In this study, the Cellic ${ }^{\circledR}$ CTec was used for fed-batch prehydrolysis prior to ethanol production by simultaneous saccharification and fermentation (SSF) way at $20 \%(\mathrm{w} / \mathrm{v})$ solid loading. It could produce $35.76 \mathrm{~g} / \mathrm{L}$ or $4.6 \%(\mathrm{v} / \mathrm{v})$ of ethanol concentration and 83.67 L/ton dry matter (DM) of yield.
\end{abstract}

Key words: Rice straw, sulfuric acid, commercial cellulase, pretreatment, fermentation, ethanol.

\section{Introduction}

Ethanol production from lignocellulosic materials is more interesting as a potential alternative to the fossil fuels and sustainable availability due to its renewable nature. To make cellulosic ethanol production be achieved in industrials scales and can be competed with fossil fuel, it requires low cost of conversing lignocellulose to ethanol, which demands not only high yield of ethanol but also high ethanol concentration in the fermentation broth to reduce distillation energy cost [1]. A way of achieving this is the increase of substrate concentration in the slurry $[2,3]$. So, the high ethanol concentration inevitably requires higher solids loading during the enzymatic hydrolysis by using lignocellulose as the feedstock [4].

Corresponding author: Teerapatr Srinorakutara, Ph.D., research field: biofuel technology. E-mail: teerapatr@tistr.or.th; teerapatr_tistr@yahoo.com.
Strategy of ethanol production by simultaneous saccharification and fermentation (SSF) has been reported to have many advantage superior to separate hydrolysis and fermentation (SHF) [2, 5-8], such as low level of end-production inhibition, low investment cost, short time to operation and low enzyme dosage for cellulose hydrolysis, etc.. However, increasing the solid loading in SSF has been shown to result in the reduced ethanol yield [2]. High solid loading of SSF will encounter with two crucial problems-high viscosity of slurry and unsuitable temperature of enzymatic hydrolysis. High viscosity of slurry is cause to many problems, including insufficient mixing and heat transfer [2, 4], shear inactivation of cellulase, decrease in water availability, irreversible blinding of adsorbed enzymes to substrate and enzyme denaturation. There may also be other reasons, as yet unidentified, for decreased conversion [1]. Whereas, unsuitable temperature of cellulase enzymatic 
hydrolysis will supplement the difficulty of hydrolysing substrate to fermentable sugar. To overcome these problems, many researchers used the SSF in fed-batch mode to maintain the low level of viscosity in slurry [2], screened and induced yeast to fermentation at high temperature, and used genitic engineering to thermo-tolerant yeast $[5,9,10]$.

The purpose of this study was to investigate the effect of commercial cellulase enzymes on ethanol production by SSF mode.

\section{Materials and Methods}

\subsection{Raw Materials and Enzymes}

Rice straw was obtained from Nakhon Pathom province, Central of Thailand. It was cut into small size $(<30.00 \mathrm{~mm})$ using vegetable chopper. The chopped rice straw was later sieved to $2.0-5.0 \mathrm{~mm}$ and kept in plastic bag for this study.

The Accellerase $1000^{\mathrm{TM}}$, Accelerase $1500^{\mathrm{TM}}$ and Cellic ${ }^{\circledR}$ CTec enzymes were commercial products. The Accellerase $1000^{\mathrm{TM}}$ and Accelleras $1500^{\mathrm{TM}}$ enzyme (Genencor) were bought from Siam Victory Chemicals Ltd.; the Cellic ${ }^{\circledR}$ CTec enzyme (Novozymes) was bought from East Asiatic (Thailand) Company Ltd..

\subsection{Pretreatment Rice Straw by Sulfuric Acid}

Sulfuric acid pretreatment of rice straw size 2.0-5.0 $\mathrm{mm}$ was carried out in $250 \mathrm{~mL}$ Duran bottle. The chopped rice straw was suspended in $1.0 \%(\mathrm{w} / \mathrm{v})$ $\mathrm{H}_{2} \mathrm{SO}_{4}$ in ratio of 15:100 (w/v) of rice straw and $\mathrm{H}_{2} \mathrm{SO}_{4}$. The samples were then heated in autoclave at $121{ }^{\circ} \mathrm{C}$ for $15 \mathrm{~min}$. The pretreated samples were cooled and adjusted $\mathrm{pH}$ to 5.0 with $\mathrm{NaOH}$. Wet blending was subsequently done using fruit blender. These samples were then filtrated through filter paper (Whatman No. 1) with vacuum filtration. The pretreated rice straw composing of $75 \%(w / w)$ moisture content was analyzed by moisture analyzer. The pretreated rice straws were finally collected at $5{ }^{\circ} \mathrm{C}$ for next experiment.

\subsection{Enzymatic Hydrolysis of Rice Straw}

The pretreated rice straws were adjusted to $15.0 \%$ (w/v) by $0.5 \mathrm{M}$ sodium citrate buffer with $\mathrm{pH} 5.0$ and incubated at $50{ }^{\circ} \mathrm{C}, 160 \mathrm{rpm}$ for $10 \mathrm{~min}$ to allow optimal temperature for enzyme hydrolysis. The commercial enzymes were then added into the slurries and incubated at $50{ }^{\circ} \mathrm{C}$ and $200 \mathrm{rpm}$. The samples were periodically taken, centrifuged and analyzed for reducing sugar. After $72 \mathrm{~h}$, the hydrolysates were separated from slurry by using vacuum filtration passing through filter paper and used for ethanol fermentation.

\subsection{Ethanol Fermentation}

Cellulosic ethanol production by SSF application were carried out in $250 \mathrm{~mL}$ Duran bottle with shaking incubator for mixing and heat transferring. The SSF strategy was introduced as seen in Fig. 1a. The pretreated rice straws were adjusted to $15 \%(\mathrm{w} / \mathrm{v})$ and $20 \%$ (w/v) by $0.5 \mathrm{M}$ sodium citrate buffer with $\mathrm{pH} 5$. The commercial cellulase enzyme, nutrients and yeast S. cerevisiae TISTR 5596 starter were added into the slurry at the same time. The slurry was carried out at $35{ }^{\circ} \mathrm{C}$ throughout of operation. After $48 \mathrm{~h}$, the slurry was harvested, filtrated through the filter paper with vacuum filtration and analyzed for reducing sugars and ethanol concentration. The batch prehydrolysis prior to simultaneous saccharification and fermentation (BP-SSF) way was introduced as seen in Fig. 1b. Like SSF strategy, the pretreated rice straws were adjusted to $15 \%(\mathrm{w} / \mathrm{v})$ and $20 \%(\mathrm{w} / \mathrm{v})$ by $0.5 \mathrm{M}$ sodium citrate buffer with $\mathrm{pH} 5$. However, the slurries were carried out at $50{ }^{\circ} \mathrm{C}$ for $24 \mathrm{~h}$ of enzymatic hydrolysis. After that, the temperature was dropped to $35{ }^{\circ} \mathrm{C}$. The nutrients and yeast $S$. cerevisiae TISTR 5596 were added into the slurry. After $48 \mathrm{~h}$, the slurry was harvested, filtrated through the filter paper with vacuum filtration and analyzed for reducing sugars and ethanol concentration. The fed-batch prehydrolysis prior to simultaneous saccharification and fermentation (FBP-SSF) way was introduced as 

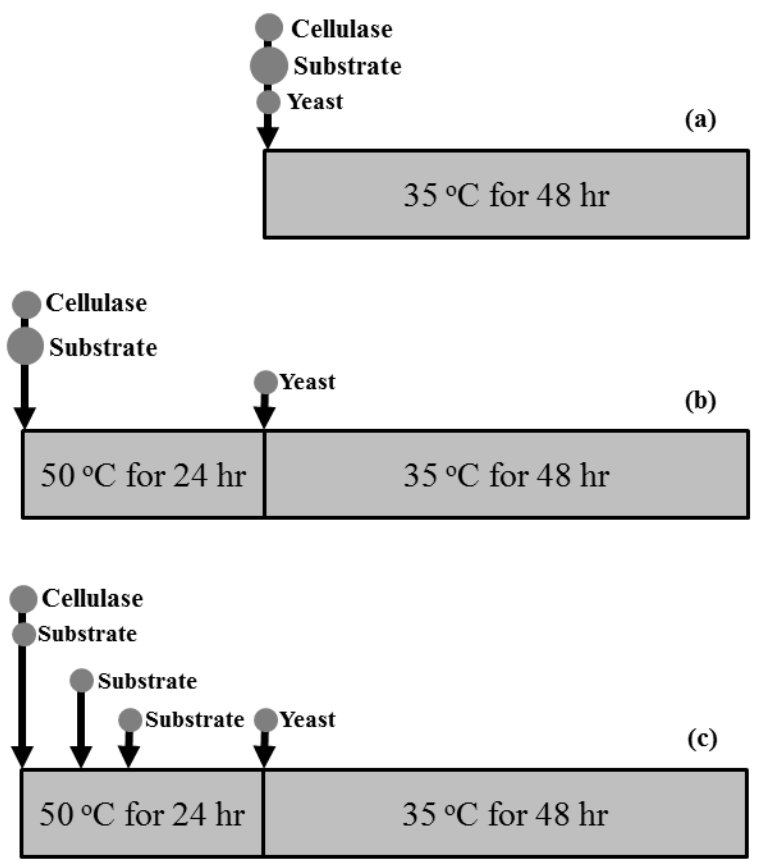

Fig. 1 The schematic diagram of ethanol production through methods of SSF (a), BP-SSF (b) and FBP-SSF (c).

seen in Fig. 1c. The pretreated rice straws were divided and fed into the $0.5 \mathrm{M}$ sodium citrate buffer with $\mathrm{pH} 5$ at $0 \mathrm{~h}$ and $6 \mathrm{~h}$ during enzymatic hydrolysis at $50{ }^{\circ} \mathrm{C}$ for $24 \mathrm{~h}$. The final solids loadings were $15 \%$ $(\mathrm{w} / \mathrm{v})$ and $20 \%(\mathrm{w} / \mathrm{v})$. After that, the temperature was dropped to $35{ }^{\circ} \mathrm{C}$. The nutrients and yeast $S$. cerevisiae TISTR 5596 were added into the slurry. After $48 \mathrm{~h}$, the slurry was harvested, filtrated through the filter paper with vacuum filtration and analyzed for reducing sugars and ethanol concentration.

All of SSF applications, the stirring rate was maintained at $200 \mathrm{rpm}$. Commercial enzyme was selected from batch enzymatic hydrolysis and used in the dosage of $45 \mathrm{FPU} / \mathrm{g}$ DM. The nutrients consist of $1.0 \mathrm{~g} / \mathrm{L}$ of yeast extract, $0.5 \mathrm{~g} / \mathrm{L}$ of $\left(\mathrm{NH}_{4}\right)_{2} \mathrm{SO}_{4}$ and $0.025 \mathrm{~g} / \mathrm{L}$ of $\mathrm{MgSO}_{4} \cdot 7 \mathrm{H}_{2} \mathrm{O}$.

\subsection{Measurement of Cellulolitic Activity}

The cellulolitic activity was measured by method of Ghose [11], using Whatman No. 1 filter paper as a substrate. Filter paper was cut into strips, $50 \mathrm{mg}$ in weight for each strip. The filter paper strip was rolled and placed into a test tube with $1.0 \mathrm{~mL}$ of sodium citrate buffer with $\mathrm{pH} 4.8$ and incubated at $50{ }^{\circ} \mathrm{C}$. The
$0.5 \mathrm{~mL}$ of dilute enzyme was then added. The mixture was incubated at $50{ }^{\circ} \mathrm{C}$ for $1 \mathrm{~h}$. Further, the reaction was stopped by placing the tube in the boiling water for $5 \mathrm{~min}$. The reducing sugar concentration was then measured by 3,5-dinitrosalicylic acid (DNS) method [12]. All assays were carried out in triplicate.

\subsection{Measurement of Reducing Sugar}

The concentration of reducing sugar from batch commercial enzymatic hydrolysis and cellulosic ethanol production strategies was analyzed by DNS method [12].

\subsection{Measurement of Ethanol}

Ethanol concentration was analyzed by gas chromatography (GC) method with HP-INNOWAX $19091 \mathrm{~N}-133$ column of a length $30 \mathrm{~m}$, outer diameter $0.251 \mathrm{~mm}$ and inner diameter $0.25 \mu \mathrm{m}$ at column temperature increased rate of $15{ }^{\circ} \mathrm{C} / \mathrm{min}$ to $120^{\circ} \mathrm{C}$, and inject temperature $220{ }^{\circ} \mathrm{C}$. Helium (He) was carrier gas at flow rate $50 \mathrm{~mL} / \mathrm{min}$ and analyzed by flame-ionized detector (FID).

\subsection{Calculation}

The rice straw conversion was calculated by Eq. (1):

Rice straw conversion (mg/g DM) = reducing sugar content in hydrolysate (mg)

/initial rice straw (g DM)

Percentage removal of hemicellulose and lignin is amount of hemicellulose and lignin loss during acid-pretreatment comparing to amount of hemicellulose and lignin in raw materials. And its calculation follows Eqs. (2) and (3):

Lignin removal $(\%)=$ loss of lignin $(g) \times$ 100/initial amount of lignin (g)

The loss of lignin ( $\mathrm{g}$ ) = initial lignin (g) -

lignin residue after acid pretreatment (g)

Ethanol yield can be calculated from ethanol produced (L) based on 1.0 ton of initial dried rice straw used. 


\section{Results and Discussion}

\subsection{Effect of Acid-Pretreatment on Pretreated Rice Straw}

To obtain the high porosity and higher cellulose hydrolysis of rice straw to fermentable sugar by cellulose enzyme, the rice straw was treated with $1.0 \%$ (w/v) $\mathrm{H}_{2} \mathrm{SO}_{4}$ and heated with autoclave at $121^{\circ} \mathrm{C}$ for $15 \mathrm{~min}$ to remove hemicellulose and lignin. After sulfuric acid pretreatment, it could be removed $65.2 \%$ (w/w) of hemicellulose and 27.8\% (w/w) of lignin. The cellulose was lost only $3.7 \%$ (w/w) as shown in Table 1 . These results led to the increase in cellulose from $38.4 \%(\mathrm{w} / \mathrm{w})$ to $50.8 \%(\mathrm{w} / \mathrm{w})$, as hemicellulose remained only $11.1 \%(\mathrm{w} / \mathrm{w})$.

Sulfuric acid pretreatment gave high efficiency for removal of hemicellulose and lignin. The pretreatment may increase porosity of rice straw. Therefore, it is easy for cellulase enzyme accessible to cellulose and then hydrolyze to sugar.

Solid residue of rice straw after sulfuric acid pretreatment was $72.8 \%$. Some of cellulose was therefore lost. However, the pretreated solid could still produce maximum ethanol $265 \mathrm{~L}$ from cellulose residues in pretreated solid (Fig. 2). This is an advantage of pretreatment. Sun and Cheng [13] reported that pretreatment not only must improve the formation of sugars or the ability to subsequently form sugars by enzymatic hydrolysis but also avoid the degradation or loss of carbohydrate.

However, the pretreated rice straws still remain high lignin to $11.3 \%(\mathrm{w} / \mathrm{w})$. This level of lignin may hinder enzyme activity accessible to cellulose and hydrolysis.

\subsection{Effect of Commercial Cellulase Enzymes on Batch Enzymatic Hydrolysis}

The activity of commercial cellulase enzyme after filter paper assay (FPA) showed that the Cellic ${ }^{\circledR}$ CTec enzyme gave the highest activity (534.24 FPU/mL), while Accellerase $1500^{\mathrm{TM}}$ gave the lowest activity (262.48 FPU/mL) and Accellerase $1000^{\mathrm{TM}}$ gave the activity of $299.33 \mathrm{FPU} / \mathrm{mL}$ (Table 2). Therefore, the volume of Cellic ${ }^{\circledR}$ CTec used was the lowest and Accellerase $1500^{\mathrm{TM}}$ used was the highest for enzymatic hydrolysis at $45 \mathrm{FPU} / \mathrm{g}$ DM. The Cellic ${ }^{\circledR}$ CTec used was only $0.08 \mathrm{~mL} / \mathrm{g}$ of $\mathrm{DM}$, while Accellerase $1500^{\mathrm{TM}}$ used was $0.17 \mathrm{~mL} / \mathrm{g} \mathrm{DM}$ (Table 2).

After batch enzymatic hydrolysis at $15 \%$ solid with enzyme 45 FPU/g DM, reducing sugar and rice straw conversion were produced as shown in Fig. 3a. Although the lowest volume of enzyme used was only $0.08 \mathrm{~mL} / \mathrm{g} \mathrm{DM}$, the Cellic ${ }^{\circledR}$ CTec gave the highest

Table 1 The chemical composition of non- and pretreated rice straw.

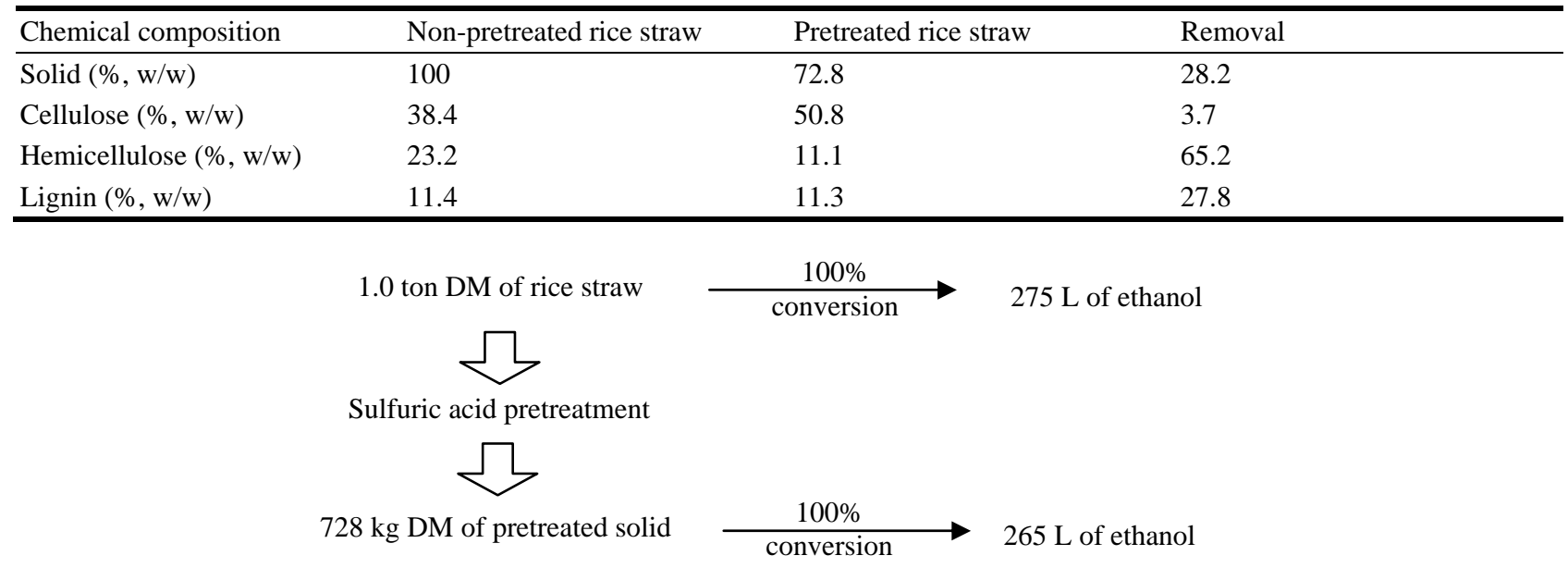

Fig. 2 Theoretical maximum of ethanol from cellulose in rice straw and pretreated rice straw. 
Table 2 Commercial cellulose enzymes activity and enzyme dosages used for batch enzymatic hydrolysis at $15.0 \%$ solid.

\begin{tabular}{llll}
\hline Commercial cellulase enzymes & $\begin{array}{l}\text { Enzyme activity } \\
\text { (FPU/mL) }\end{array}$ & $\begin{array}{l}\text { Fixed activity } \\
(45 \mathrm{FPU} / \mathrm{g} \mathrm{DM})\end{array}$ & $\begin{array}{l}\text { Fixed volume } \\
(0.13 \mathrm{~mL} / \mathrm{g} \mathrm{DM})\end{array}$ \\
\hline Accellerase $1000^{\mathrm{TM}}$ & 299.33 & $0.15 \mathrm{~mL} / \mathrm{g} \mathrm{DM}$ & $0.13 \mathrm{~mL} / \mathrm{g} \mathrm{DM}$ \\
Accellerase $1500^{\mathrm{TM}}$ & 262.48 & $0.17 \mathrm{~mL} / \mathrm{g} \mathrm{DM}$ & $0.13 \mathrm{~mL} / \mathrm{g} \mathrm{DM}$ \\
Cellic ${ }^{\circledR} \mathrm{CTec}$ & 534.24 & $0.08 \mathrm{~mL} / \mathrm{g} \mathrm{DM}$ & $0.13 \mathrm{~mL} / \mathrm{g} \mathrm{DM}$ \\
\hline
\end{tabular}

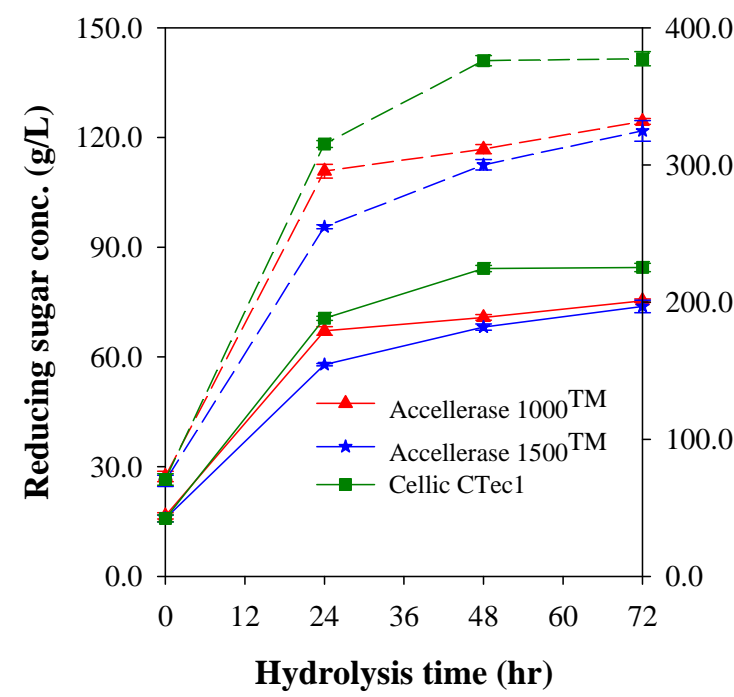

(a)

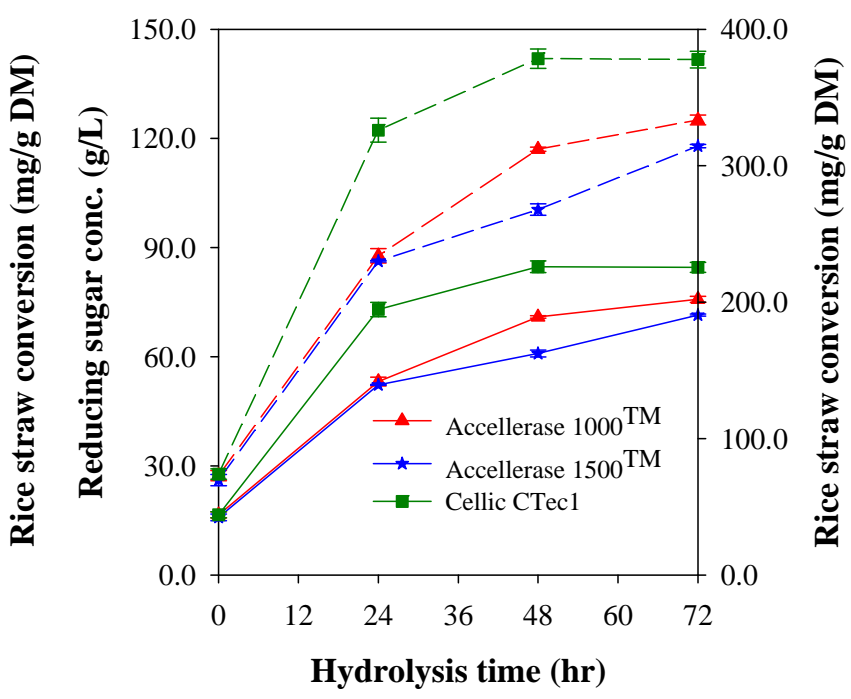

(b)

Fig. 3 Reducing sugar concentration and rice straw conversion were obtained from batch enzymatic hydrolysis at $15 \%$ solid with enzyme dosage of $45 \mathrm{FPU} / \mathrm{g}$ DM (a) and $0.13 \mathrm{~mL} / \mathrm{g} \mathrm{DM}$ (b).

productivity, reducing sugar concentration and rice straw conversion. As volume of the Accellerase $1500^{\mathrm{TM}}$ used was the highest $(0.17 \mathrm{~mL} / \mathrm{g} \mathrm{DM})$, its productivity, reducing sugar concentration and rice straw conversion was the lowest. Batch enzymatic hydrolysis at $15 \%$ solid was tested by using $0.13 \mathrm{~mL} / \mathrm{g}$ DM for every type of enzymes (Fig. 3b). The Cellic ${ }^{\circledR}$ $\mathrm{CTec}$ gave the highest productivity, reducing sugar concentration and rice straw conversion. Moreover, when the Cellic ${ }^{\circledR}$ CTec hydrolysate was fermented with S. cerevisiae TISTR 5596, it gave the highest ethanol concentration (Fig. 4). This indicated that the Cellic ${ }^{\circledR}$ CTec was not only a good convertor for changing pretreated rice straw to reducing sugar, but also a high quality of sugar producer for ethanol production.

To achieve an ethanol production at high solid loading, the Cellic ${ }^{\circledR}$ CTec was selected for next experiment because of its high efficiency of hydrolysis of the pretreated rice straw and consumption of the lowest volume of enzyme. In addition, the hydrolysate obtained from Cellic ${ }^{\circledR}$ CTec gave the highest ethanol concentration after fermentation with S. cerevisiae TISTR 5596.

\subsection{Ethanol Production Way by SSF Application}

Ethanol production by SSF at $15 \%$ and $20 \%$ solid loading, respectively, gave the lowest ethanol concentration and yield comparing to BP-SSF and FBP-SSF as shown in Figs. 5 and 6. In addition, ethanol concentration and yield of SSF severely decreased as solid loading increased from $15 \%$ to $20 \%$ solid. This result showed disadvantage of ethanol production by SSF at high solid loading. Many papers reported that ethanol production by SSF maintained low level of end-production inhibition, leading to the achieving of high overall of ethanol yield [2, 5-8]. However, these cases were not success at high solid 


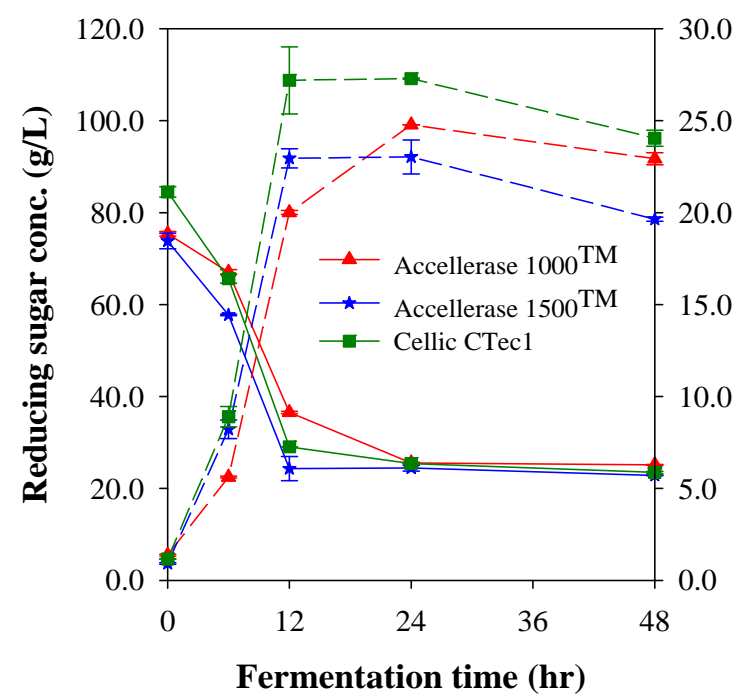

(a)

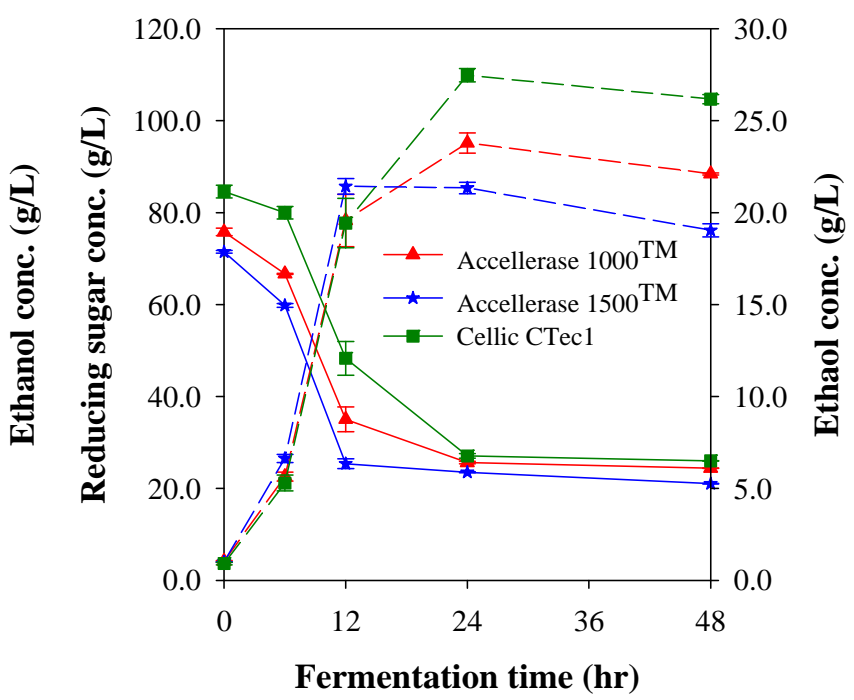

(b)

Fig. 4 Ethanol productions by $S$. cerevisiae TISTR 5596 of hydrolysates obtained from batch enzymatic hydrolysis at $15 \%$ solid with enzyme dosage of 45 FPU/g DM (a) and $0.13 \mathrm{~mL} / \mathrm{g} \mathrm{DM}$ (b).

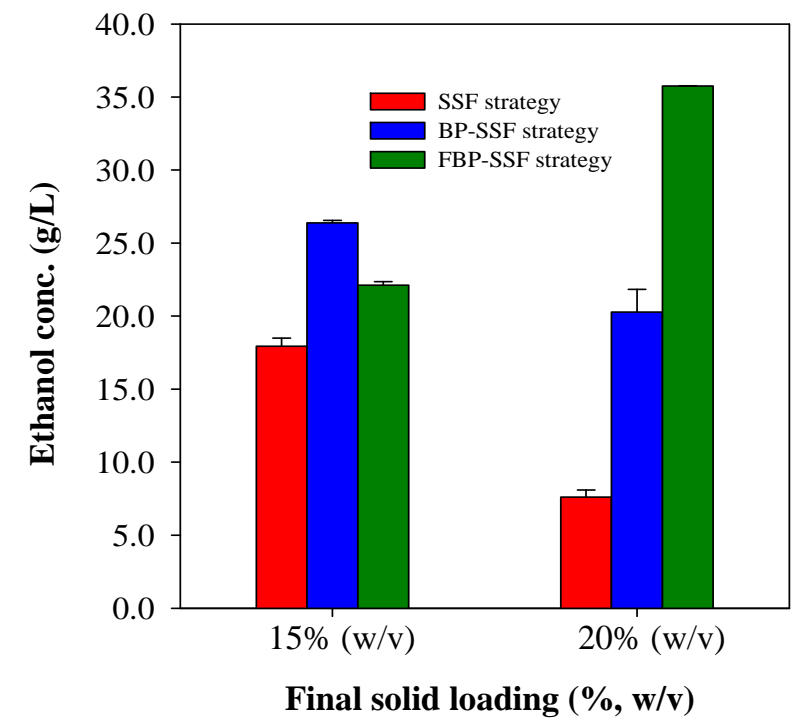

Fig. 5 Comparison of ethanol concentration obtaining from ethanol production by SSF, BP-SSF and FBP-SSF.

loading, because high solid loading would create the other crucial problems, especially high viscosity of slurry.

High viscosity not only creates hard mixing and heat transfer, but also leads to lacking an available water of slurry. These results cause the difficulty of enzyme diffusion to the surface of material according to Matsakas and Chistakopoulos [14]. They reported that the initial DM loading up over 15\% created no

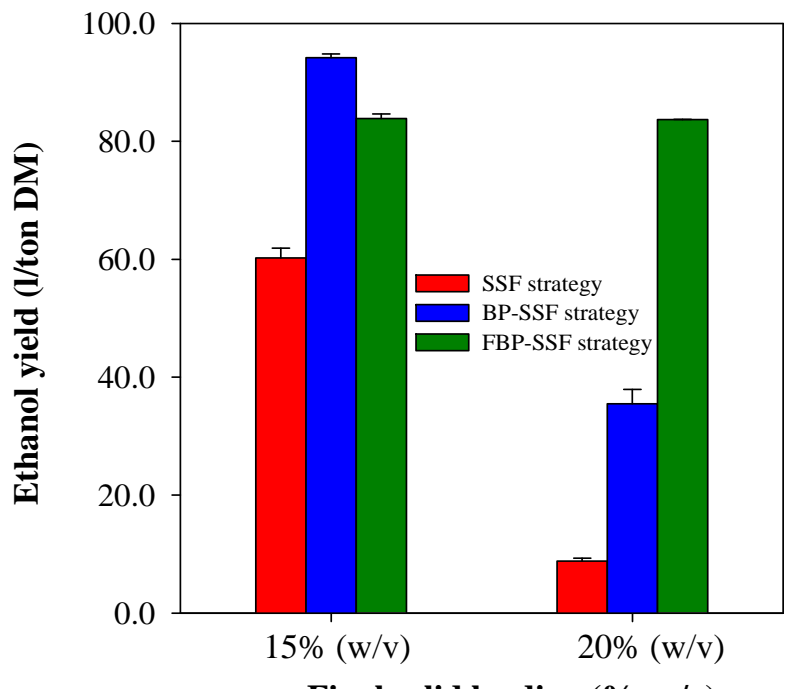

Final solid loading $(\%, w / v)$

Fig. 6 Comparison of ethanol yield obtaining from ethanol production by SSF, BP-SSF and FBP-SSF.

free water existing in the slurry of batch hydrolysis, leading to the difficulty of slurry handling. In addition, an activity of cellulase enzyme for ethanol production by means of SSF will encounter with unsuitable temperature of hydrolysis, because it will be used at temperature lower than $50{ }^{\circ} \mathrm{C}$ for yeast growth. This leads to the difficulty of hydrolysing the substrate to fermentable sugar. Finally, ethanol concentration and yield will decrease. 
In this ethanol production, when BP-SSF was applied, it would give the higher ethanol concentration and yield than SSF. This may be due to the BP-SSF consisting of prehydrolysis that help the decrease in viscosity of slurry prior to SSF. The slurry of BP-SSF was easier to handle than slurry of SSF. Similar to ethanol production by SSF, the BP-SSF at $20 \%$ solid gave the lower ethanol concentration and yield than BP-SSF at $15 \%$ solid, because all substrate was added at the beginning of process both SSF and BP-SSF. Therefore, the slurry had high viscosity and low free water (Fig. 7). Although ethanol production by BP-SSF started with prehydrolysis to decrease viscosity of slurry prior to ethanol production by SSF, however batch prehydrolysis did not be effective at $20 \%$ solid. The slurry still had high viscosity and was difficult to handle.

The results indicated that batch prehydrolysis could reduce viscosity and gave a good hydrolysis at 15\% solid or lower, as batch prehydrolysis at $20 \%$ solid could decrease a little viscosity only. To achieve high efficiency of cellulosic ethanol production, the problem of high viscosity slurry should be considered as the first priority in this study.

The application of FBP-SSF in ethanol production would increase the ethanol concentration from 22.12 $\mathrm{g} / \mathrm{L}$ to $35.76 \mathrm{~g} / \mathrm{L}$ or $4.6 \%(\mathrm{v} / \mathrm{v})$ when solid loading increased from $15 \%$ to $20 \%$ solid. In addition, ethanol

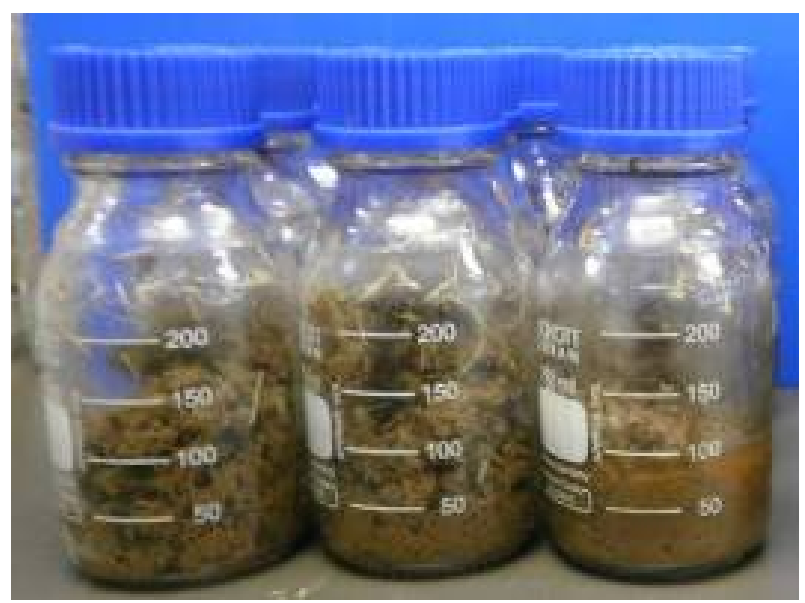

(a) (c)

production by FBP-SSF at 20\% solid gave more ethanol concentration of 4.7 and 1.8 times and more ethanol yield of 9.5 and 2.4 times comparing to SSF and BP-SSF, respectively.

Ethanol production by FBP-SSF gave the different result from ethanol production by SSF and BP-SSF. As solid loading increased from $15 \%$ to $20 \%(\mathrm{w} / \mathrm{v})$, the pretreated solids of ethanol production by FBP-SSF were divided before feeding into hydrolyser during prehydrolysis. The viscosity of slurry could be maintained at low level. Besides, the system created the high free water in the slurry and the ease of its mixing. The enzyme was easy to diffuse into surface of substrate leading to good hydrolysis. The slurry of FBP-SSF would have the lowest initial solid comparing to SSF and BP-SSF as seen in Fig. 7. Moreover, the slurry of ethanol production by FBP-SSF also had the initial fermentable sugar before adding yeast [5]. This helped yeast growth and sugar consumption rapidly.

To achieve economic value of industrial ethanol production, the fermented broth for industrial ethanol distillation must have high ethanol concentration. Unfortunately, the high solids loading will be therefore used inevitably during the enzymatic hydrolysis. The high solid loading creating crucial problem was high viscosity of slurry as shown in above results. Many researchers tried to overcome this

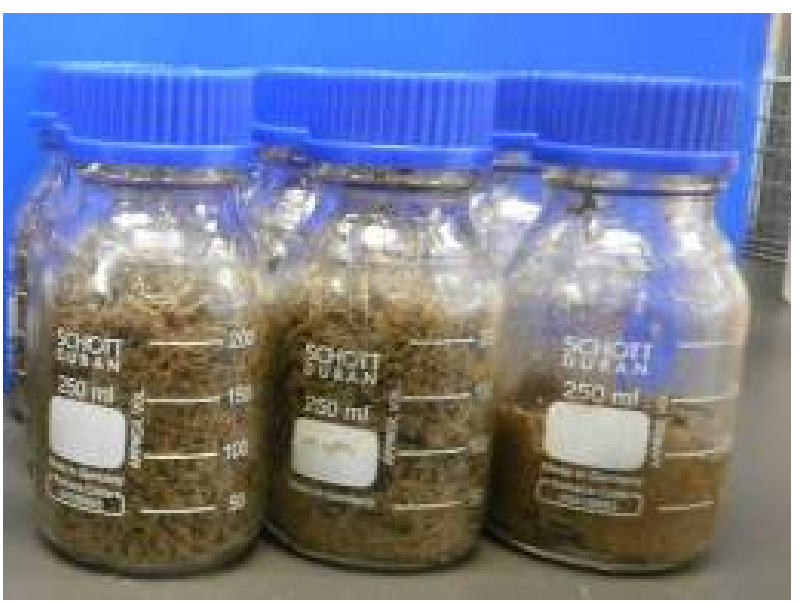

(a)

(b)

(c)

Fig. 7 The initial slurry of SSF (a), BP-SSF (b) and FBP-SSF (c) at $15 \%$ and $20 \%$, respectively. 
problem by decrease in slurry viscosity before ethanol production by SSF. Chu et al. [9] used prehydrolysis at $50{ }^{\circ} \mathrm{C}$ for $12 \mathrm{~h}$ prior to ethanol production by SSF. Su et al. [5] also used prehydrolysis at $50{ }^{\circ} \mathrm{C}$ for $24 \mathrm{~h}$ before ethanol production by simultaneous saccharification and co-fermentation (SSCF). Zhu et al. [15] used liquefaction at $50{ }^{\circ} \mathrm{C}$ for $120 \mathrm{~h}$ before ethanol production by SSF. Although it could give high ethanol concentration over the benchmark level (above $4.0 \%(\mathrm{v} / \mathrm{v})$ ) [5, 16, 17], it might be economically viable to produce in large scale. However, almost of material pretreatment was used in high severity condition, especially high temperature, such as Chu et al. [9] pretreated corn stover at $190^{\circ} \mathrm{C}$ for $3 \mathrm{~min}$, Zhu et al. [15] pretreated aspen at $170{ }^{\circ} \mathrm{C}$ for $10 \mathrm{~min}$, and Albuquerque-Wanderley et al. [18] pretreated sugarcane bagasse at $200{ }^{\circ} \mathrm{C}$ for $7 \mathrm{~min}$. In addition, the mixing with higher efficiency than incubator shaker was used, such as Chu et al. [9] used helical stirring for mixing and fermented by thermotolerant yeast strain $S$. cerevisiae DQ1 at $40{ }^{\circ} \mathrm{C}$.

Ethanol production by FBP-SSF at 20\% solid could produce ethanol of $35.76 \mathrm{~g} / \mathrm{L}$ or $4.6 \%(\mathrm{v} / \mathrm{v})$, which was close to benchmark level (above $4.0 \%(\mathrm{v} / \mathrm{v})$ ). This may be economically viable to produce in large scale $[5,16,17]$. The result showed that ethanol production by FBP-SSF was a good manner for cellulosic ethanol production. Moreover, the raw material pretreatment in this study was done at low severe condition. The pretreatment was done in autoclave at $121^{\circ} \mathrm{C}$ for 15 min merely. It was low temperature and safety for operation.

However, ethanol yield of FBP-SSF at 20\% solid was very low comparing to ethanol production of Zhu et al. [15], which could produce ethanol from aspen up to $133 \mathrm{~L} /$ ton DM. To increase ethanol yield, research and development of ethanol production by FBP-SSF should be therefore done further study.

\section{Conclusions}

The commercial Cellic ${ }^{\circledR}$ CTec was the best enzyme for conversion of pretreated rice straw to reducing sugar when compared with commercial Accellerase $1000^{\mathrm{TM}}$ and Accelerase $1500^{\mathrm{TM}}$ enzymes in this study. Moreover, the Cellic ${ }^{\circledR}$ CTec hydrolysate showed the highest quality for ethanol production.

Ethanol production by FBP-SSF was the best technique for ethanol production at $20 \%$ solid comparing to SSF and BP-SSF. In addition, it also gave ethanol concentration of $4.6 \%(\mathrm{v} / \mathrm{v})$, which was close to benchmark level for economically viable to produce in large scale.

\section{Acknowledgments}

This work was financially and facilely supported by PTT Public Company Limited and Thailand Institute of Scientific and Technological Research (TISTR).

\section{References}

[1] Puri, D. J., Heaven, S., and Banks, C. 2013. “Improving the Performance of Enzymes in the Hydrolysis of High Solids Paper Pulp Derived from MSW.” Biotechnology for Biofuels 6: 107.

[2] Hoyer, K., Galge, M., and Zacchi, G. 2010. "Effects of Enzyme Feeding Strategy on Ethanol Yield in Fed-Batch Simultaneous Saccharification and Fermentation of Spruce at High Dry Matter.” Biotechnology for Biofuels 3: 14.

[3] Kahr, H., and Jäger, A. G. 2011. "Improvement in Bioethanol Production Process from Straw.” In Proceedings of World Renewable Energy Congress 2011, 560-5.

[4] Zhang, J., Chu, D., Huang, J., Yu, Z., Dai, G., and Bao, J. 2010. "Simultaneous Saccharification and Ethanol Fermentation at High Corn Stover Solids Loading in a Helical Stirring Bioreactor.” Biotechnology and Bioengineering 105 (4): 718-28.

[5] Su, R., Ma, Y., Qi, W., Zhang, M., Wang, F., Du, R., Yang, J., Zhang, M., and He, Z. 2012. "Ethanol Production from High-Solid SSCF of Alkaline-Pretreated Corncob Using Recombinant Zymomonas mobilis CP4.” Bioenerg. Res. 6 (1): 292-9.

[6] Stenberg, K., Bollok, M., Reczey, K., Galbe, M., and Zacchi, G. 2000. "Effect of Substrate and Cellulase Concentration of Simultaneous Saccharification and Fermentation of Steam-Pretreated Softwood for Ethanol Production.” Biotechnol. Bioeng. 68 (2): 204-10.

[7] Wright, J. D., Wyman, C. E., and Grohmann, K. 1988. 
Pretreated Rice Straw at High Solid Loading

"Simultaneous Saccharification and Fermentation of Lignocellulose: Process Evalution.” Appl. Biochem. Biotechnol. 18 (1): 75-90.

[8] Wyman, C. E., Spindler, D. D., and Grohmann, K. 1992. "Simultaneous Saccharification and Fermentation of Several Lignocellulosic Feedstock to Fuel Ethanol.” Biomass and Bioenergy 3 (5): 301-7.

[9] Chu, D., Zhange, J., and Bao, J. 2012. "Simultaneous Saccharification and Ethanol Fermentation of Corn Stover at High Temperature and High Solid Loading by Thermotolerant Strain Saccharomyces cerevisiae DQ1.” Bioenerg. Res. 5 (4): 1020-6.

[10] Engardo, A., Carolina, P., Manuel, R., Juanita, F., and Jaime, B. 2008. "Selection of Thermotolerant Yeast Strains Saccharomyces cerevisiae for Bioethanol Production.” Enzyme Microb. Tech. 43 (2): 120-3.

[11] Ghose, T. K. 1987. "Measurement of Cellulase Activity." Pure Appl. Chem. 59 (2): 257-68.

[12] Miller, G. L. 1959. "Use of Dinitrosalicylic Acid Reagent for Determination of Reducing Sugar.” Anal. Chem. 31 (3): 426-8.

[13] Sun, Y., and Cheng, J. 2002. "Hydrolysis of Linocellulosic Material for Ethanol Production: A
Review.” Bioresour. Technol. 83 (1): 1-11.

[14] Massakas, L., and Christakopoulos, P. 2013. "Fermentation of Liquefacted Hydrothermally Pretreated Sweet Sorghum Bagasse to Ethanol at High-Solid Content.” Bioresource Technology 127: 202-8.

[15] Zhu, J. Y., Gleisner, R., Scott, C. T., Luo, X. L., and Tian, S. 2011. "High Titer Ethanol Production from Simultaneous Enzymatic Saccharification and Fermentation of Aspen at High Solid: A Comparison between SPORL and Dilute Acid Pretreatment.” Bioresource Technology 102 (19): 8921-9.

[16] Wingren, A., Galbe, M., and Zacchi, G. 2003. "Techno-Economic Evaluation of Producing Ethanol from Softwood: Comparison of SSF and SHF and Identification of Bottleneck.” Biotech. Progress 19 (4): 1109-17.

[17] Chen, M., Xia, L., and Xue, P. 2007. "Enzymatic Hydrolysis of Corncob and Ethanol Production from Cellulosic Hydrolysate.” Biodegration 59 (2): 85-9.

[18] Albuquerque-Wanderley, M. C. A., Martin, C., Moraes-Rocha, G. J., and Gouvia, E. R. 2012. "Increase in Ethanol Production from Sugarcane Bargasse Based on Combined Pretreatment and Fed-Batch Enzymatic Hydrolysis.” Bioresource Technology 128: 448-53. 